\title{
Infection by Xanthomonas campestris pv.viticola under temperature increase and carbon dioxide concentrations
}

\author{
Jaime Luiz Albuquerque Conceição', Francislene Angelotti², Ana Rosa Peixoto', Raquel Ghini
}

'University of State Bahia, Juazeiro, BA, Brazil;

2Brazilian Agricultural Research Corporation, EMBRAPA Semiárido, Petrolina, PE, Brazil; 'Brazilian Agricultural Research Corporation, EMBRAPA Meio Ambiente, Jaguariúna, SP, Brazil;

*Corresponding author, e-mail: francislene.angelotti@embrapa.br

\begin{abstract}
The experiments were carried out under controlled conditions to evaluate the impact of increased temperature and concentration of carbon dioxide on infection of Xanthomonas campestris pv viticola, the causal agent of bacterial canker in Vine seedlings. It proceeded the evaluation of the following epidemiological components: incubation period (PI), severity (SEV) and using that data were calculated the area under the disease progress curve (AUDPC). It used grape seedlings (Italia, Crimson Seedless, Sugraone and Selection 8) inoculated with bacterial suspension (108 CFU $\mathrm{mL}^{-1}$ ). The experimental design was completely randomized, factorial arrangement $4 \times 4$ (cultivar $x$ temperature) and $4 \times 2$ (cultivar $x$ carbon dioxide concentration) which was carried out twice. The data were subjected to variance analysis. Increasing temperature reduced bacterium's incubation period with significant differences between genotypes. For Selection 8 and Crimson temperature increase caused enhancement on severity and AUDPC. For Seleção 8 the incubation period (PI) was extended from 7.93 to 30.18 days when the concentration changed from 390 to $770 \mu \mathrm{mol} / \mathrm{mol}$. The increased $\mathrm{CO}_{2}$ concentration reduced AACPSD and SEV for Sugraone and Selection 8. The results show that the temperature and carbon dioxide $\left(\mathrm{CO}_{2}\right)$ concentration of the air may have different effects on bacterial canker of grapevine.
\end{abstract}

Keywords: bacterial canker, climate change, Vitis vinifera

\section{Introduction}

Canker is the major disease of bacterial origin in grape vine (Vitis sp.), whose causal agent is Xanthomonas campestris pv viticola (Nayudu) Dye. This disease has already been identified in São Paulo (Rodrigues Neto et al., 2011), Ceará, Roraima, Piauí, Bahia and Pernambuco (Malavolta Jr et al., 2008) states, while in São Francisco Valley (Brazil) it is of great importance, because it is under conditions of temperature between 25 and $30^{\circ} \mathrm{C}$ and high humidity, and ultimately reduced the grape production (Lima et al., 1999). According to Lima \& Ferreira (2012), the symptoms of this disease varies according to the tolerance of each cultivar and the environmental conditions.

The human activities, especially in the last 150 years, have contributed to the elevation in the world temperature due to the ever increasing concentration of greenhouse gases. The concentration of carbon dioxide $\left(\mathrm{CO}_{2}\right)$ has increased by approximately $40 \%$ since 1750 , with an estimated increase of 730 to $1020 \mu \mathrm{mol} / \mathrm{mol}$ for the A2 scenario (worst case). As a consequence of increasing greenhouse gases amount, the average temperature has risen by $0.6^{\circ} \mathrm{C}$, with an estimated increase of $1.4{ }^{\circ} \mathrm{C}$ to $5.8^{\circ} \mathrm{C}$ until 2100 (IPCC 2007, IPCC 2013).

It is known that the environment affects directly all developmental stages of both the 
pathogen and the host plant, and thus the climate change may interfere with the geographic and temporal distribution of diseases (Ghini et al., 2012). According to Beriam et al. (2011), species of plant-pathogenic bacteria may react in different ways to environmental changes, which can have deleterious or beneficial effects, or even not cause changes in the life cycle and pathogenicity of plant bacteria, though they may change the physiology and resistance of the host plant. However, few studies have been carried out to effectively simulate the effect of climate change on pathogens (Garrett et al., 2006) and host plants to develop measures of mitigation and adaptation for the disease management (Chakraborty \& Newton, 2011).

The objective of this study was to evaluate the effect of temperature increase and concentration of atmospheric carbon dioxide on infection by Xanthomonas campestris pv. viticola in four grape vine cultivars.

\section{Material and Methods}

The first experiment was conducted in the facilities of the Department of Technologies and Social Sciences (DTCS) of Universidade do Estado da Bahia - UNEB, Campus III, located in Juazeiro/BA, Brazil (geographical coordinates $9^{\circ}$ $24^{\prime} \mathrm{S}$ and $40^{\circ} 30^{\prime} \mathrm{W}$ ) during the first semester of 2012, in laboratory and greenhouse conditions. The second experiment consisted of evaluations performed at the Climate Change Sector of Embrapa Tropical Semiarid, located in Petrolina/ PE, Brazil ( $9^{\circ} 09^{\prime} S$ and $40^{\circ} 22^{\prime} \mathrm{W}$ ) during the second semester of 2012.

The trials were conducted with grape vine (Vitis vinifera) seedlings with four different materials, as follows: three cultivars (Italia, Crimson seedless and Sugraone) and a selection from the Active Germplasm Bank of Embrapa Grape and Wine (Seleção 8), cultivated in polyethylene bags $(0.22 \times 0.14 \mathrm{~m})$, using rooted cuttings of grape vines from commercial areas, propagated via stem cuttings. The substrate was prepared using organic compost + sand $(1: 1)$.

Before and after inoculation, the seedlings were placed in a moist chamber for 24 hours. The pre-treatment aimed to promote stomatal opening, facilitating the pathogen penetration, whereas the post-treatment was performed to ensure the water congestion in the adjacent tissues, which is crucial to the infectious process (Romeiro, 2005).

For inoculation, the methodology proposed by Nascimento et al. (2006) was adopted, in which double gauze swabs moistened with $0.5 \mathrm{~mL}$ of the bacterial suspension were gently rubbed on the leaf surfaces. The bacterial suspension, prepared in sterilized distilled water was obtained from the isolate Xanthomonas campestris pv. viticola (Xcv3) derived from the collection of bacterial cultures of the Plant Pathology Laboratory of UNEB, collected from a commercial area of production of fine table grapes in the irrigated area of Irrigated Perimeter Senador Nilo Coelho, in Petrolina/PE (Brazil), cultivated with Red Globe grape cultivar. Using a photocolorimeter at 570 $\mathrm{nm}$, the suspension was adjusted to $10^{8} \mathrm{CFU} \mathrm{\textrm {mL } ^ { - 1 }}$ $\left(A_{570}=0.4\right)$ concentration.

\section{Experiment I - Effect of temperature}

After the treatment in moist chamber, the plants were inoculated and subjected to different temperatures in a B.O.D. (Biological Oxygen Demand) growth chamber, 12-h photoperiod, during $48 \mathrm{~h}$. Inoculation occurred at 45 days after the seedlings were planted, using five leaves per plant, totaling 20 leaves per genotype. Subsequently, all seedlings were kept in a greenhouse at 26 to $30^{\circ} \mathrm{C}$ with relative humidity above $70 \%$ until the end of the evaluations.

\section{Experiment II - Effect of $\mathrm{CO}_{2}$ concentration}

The treatments were distributed in a 4 $\times 4$ factorial arrangement with 20 replicates, as follows: four temperatures $(26.0,28.0,29.1$ and $31.8^{\circ} \mathrm{C}$ ) and four genotypes [Sugraone, Italia, Crimson Seedless and Seleção 8 (Embrapa Grape and Wine)]. The temperature values adopted corresponded to the local average temperature with an addition of 2, 3.1 and 5.8 ${ }^{\circ} \mathrm{C}$, respectively referring to the future scenarios B1, B2 and A IF estimated by the IPCC (2007). The experiment was conducted twice.

Four leaves were inoculated per plant for the experiment with $\mathrm{CO}_{2}$, totaling 16 leaves 
per cultivar. After the inoculation, the seedlings were subjected to the concentrations of 390 and $770 \mu \mathrm{mol} / \mathrm{mol} \mathrm{CO}$ in growth chambers at $29^{\circ} \mathrm{C}$ and relative humidity above $70 \%$. After $48 \mathrm{~h}$, the plants were transferred to a greenhouse under humidity above $70 \%$ and average temperature $29^{\circ} \mathrm{C}$, and evaluated daily until the end of the experiment.

The experimental design was completely randomized, in a $4 \times 2$ factorial arrangement represented by four genotypes (Sugraone, Italia, Crimson Seedless and Seleção 8 (Embrapa Grape and Wine) and two concentrations of $\mathrm{CO}_{2}$ (390 and $770 \mu \mathrm{mol} / \mathrm{mol}$ ). The experiment was performed twice.

For the two experiments, all plants were evaluated for five weeks, recording the following epidemiologic components: a) period of incubation (PI), corresponding to the number of days between inoculation and appearance of the first symptoms; and b) severity of the disease (SEV), determined using a diagrammatic scale (Nascimento et al., 2005), which showed severity levels of the diseased leaf area varying from 2 to $91 \%$. The evaluations were performed every seven days, for five consecutive weeks.

From the data obtained during the evaluations of severity, it was possible to determine the area under the disease progress curve (AUDPC), calculated by the expression: AUDPC $=\sum(y i+y i+1) / 2 . d t i$, where yi and $y i+1$ correspond to the severity values found in two consecutive assessments, and dti is the interval (in days) between the assessments (Shaner \& Finney, 1977).

The obtained data were subjected to variance analysis using the Assistat (7.6 Beta) statistical software and the means were grouped by the Scott-Knott test ( $\mathrm{p} \leq 5 \%$ ).

\section{Results and Discussion}

Experiment I - Effect of temperature

The symptoms of bacterial canker were observed in all cultivars, for all the tested temperatures, with the period of incubation (PI) varying according to genotype and temperature (Table 1).

Table 1. Period of incubation (PI) (days) of bacterial canker in seedlings of grape cultivars under different temperatures. Juazeiro/BA, Brazil.

\begin{tabular}{cllll}
\hline \multirow{2}{*}{ Temperatures $\left({ }^{\circ} \mathrm{C}\right)$} & \multicolumn{4}{c}{ Grape cultivar/ PI } \\
\cline { 2 - 5 } & Sugraone & Crimson & Seleção 8 & Italia \\
\hline 26.0 & $13.00 \mathrm{aA}$ & $13.00 \mathrm{aA}$ & $12.70 \mathrm{aA}$ & $12.50 \mathrm{aA}$ \\
28.0 & $15.00 \mathrm{aA}$ & $9.00 \mathrm{bB}$ & $14.70 \mathrm{aA}$ & $10.75 \mathrm{aB}$ \\
29.1 & $9.90 \mathrm{bBC}$ & $9.30 \mathrm{bC}$ & $12.65 \mathrm{aA}$ & $12.20 \mathrm{aAB}$ \\
31.8 & $8.85 \mathrm{bA}$ & $5.15 \mathrm{CB}$ & $6.80 \mathrm{bAB}$ & $7.85 \mathrm{bA}$ \\
\hline $\mathrm{CV}(\%)=27.14$ & & & \\
\hline $\begin{array}{l}\text { Means followed by the same lowercase letter in the column and uppercase letter in the row do not differ by the Scott-Knott test } \\
\text { at 5\% probability. }\end{array}$
\end{tabular}

The temperature increase promoted a reduction in $\mathrm{Pl}$ for the tested cultivars. In the seedlings of Sugraone, Crimson, Seleção 8 and Italia cultivars, the increase of $5.8^{\circ} \mathrm{C}$ reduced the $\mathrm{Pl}$ from 13, 13, 12.7 and 12.5 to $8.85,5.15$, 6.80 and 7.85 days, respectively. This increase in the local average temperature $\left(26^{\circ} \mathrm{C}\right)$ favored the establishment of the disease, i.e., the time necessary for the appearance of the first symptoms. Seleção 8 and cv. Italia plants showed a decrease in PI when subjected to the temperature of $31.8^{\circ} \mathrm{C}$ only, which indicates greater tolerance to temperature increase without the occurrence of benefits for the establishment of the pathogen (Table 1).
Data obtained by Ghini et al. (2011) also showed a tendency towards a reduction in the incubation of coffee rust (Hemileia vastatrix) when simulated temperature increase.

When compared with each other, under the average temperature of $26^{\circ} \mathrm{C}$, the cultivars do not presented significant differences to the number of days between inoculation and appearance of the first symptoms. No significant difference were observed in PI for cv. Sugraone and Seleção 8 either at $28^{\circ} \mathrm{C}$, elapsing 15 and 14.7 days for the appearance of the symptoms, respectively. In seedlings exposed to $29.1{ }^{\circ} \mathrm{C}$, the shortest incubation period was observed for the Sugraone and Crimson cultivars, with 9.9 and 9.3 days, 
respectively (Table 1). Differences in incubation period reflect in differences in the growth rate of the pathogen in the host, and consequently in the disease progress rate (Parlevliet, 1979). Thus, the short incubation period observed due to the temperature elevation is a factor that contributes to the occurrence of epidemics. Moreover, it was observed that for every cultivar evaluated there was a difference in the period of incubation. According to Parlevliet (1979), PI is a component of resistance, and this variation in the time for appearance of the symptoms may be related to differences in the genotypic composition of the biological materials.

Significant differences were observed $(P=0.05)$ between the treatments for the variables severity and AUDPC (Figure 1; Table 2). The canker severity in the grape vine varied from 0.5 to $13.5 \%$ at the different temperatures evaluated. The highest values were observed when the seedlings were exposed to temperatures of 29.1 and 31.8 ${ }^{\circ} \mathrm{C}$. For Seleção 8 and Crimson, the temperature increase promoted an increase on disease severity (Figure 1).

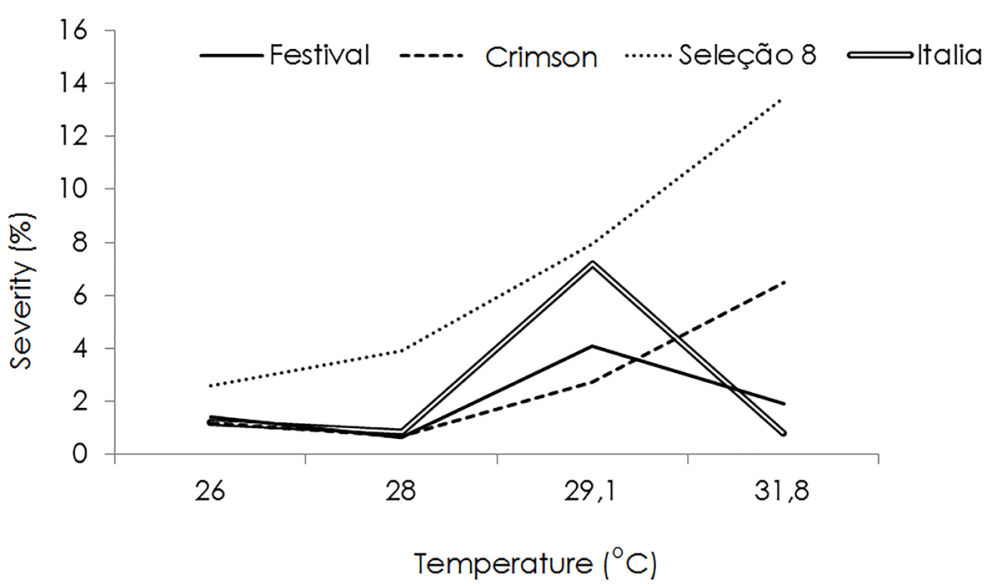

Figure 1. Severity of bacterial canker in grape vine seedlings under different temperatures. Juazeiro/BA, Brazil.

Table 2. Area under the disease progress curve (AUDPC) (bacterial canker) in seedlings of grape cultivars under different temperatures. Juazeiro/BA, Brazil

\begin{tabular}{cllll}
\hline \multirow{2}{*}{ Temperatures $\left({ }^{\circ} \mathrm{C}\right)$} & \multicolumn{4}{c}{ Grape cultivars / AUDPC } \\
\cline { 2 - 5 } & Sugraone & Crimson & Seleção 8 & Italia \\
\hline 26.0 & $13.60 \mathrm{bA}$ & $25.20 \mathrm{cA}$ & $49.70 \mathrm{cA}$ & $37.30 \mathrm{bA}$ \\
28.0 & $19.00 \mathrm{bB}$ & $19.60 \mathrm{cB}$ & $69.50 \mathrm{cA}$ & $25.40 \mathrm{bB}$ \\
29.1 & $81.30 \mathrm{aB}$ & $74.00 \mathrm{bB}$ & $113.80 \mathrm{bA}$ & $134.80 \mathrm{aA}$ \\
31.8 & $43.00 \mathrm{bB}$ & $148.00 \mathrm{aA}$ & $182.70 \mathrm{aA}$ & $17.80 \mathrm{bB}$ \\
\hline
\end{tabular}

\section{$\mathrm{CV}(\%)=54.32$}

Means followed by the same lowercase letter in the column and uppercase letter in the row do not differ by the Scott-Knott test at $5 \%$ probability.

The temperature increase also showed significant effects on infection by Ralstonia solanacearum and Xanthomonas campestris pv. vesicatoria on pepper, identified as one of the most important environmental factors in the outbreak of disease (Shin \& Yun, 2010).

The analysis of AUDPC also showed differences in susceptibility among the cultivars evaluated at the different temperatures. The worst scenario, with a temperature increase of 5.8 ${ }^{\circ} \mathrm{C}$, corresponding to $31.8^{\circ} \mathrm{C}$, provided a greater value of AUDPC for cv. Crimson and Seleção 8, with 148 and 182.70, respectively. Sugraone and
Italia cultivars presented higher values of AUDPC (81.3 and 134.8) when under the temperature of $29.1^{\circ} \mathrm{C}$ only (Table 2 ).

In citrus, the temperature increase also provoked an increase in the percentage of leaf area diseased by X. axonopodis pv. citri (Dalla Pria et al., 2006), thus in disagreement with Marcuzzo et al. (2009), who found a reduction in the development of bacterial spot of tomato plant caused by Xanthomonas spp. at temperatures above $25^{\circ} \mathrm{C}$. 
Experiment II - Effect of $\mathrm{CO}_{2}$ concentration

The symptoms of bacterial canker were observed in all grape vine varieties in the experiment in the carbon-dioxide-enriched environment. Only Seleção 8 showed a significant difference $(\mathrm{P}=0.05)$ for the incubation period at different $\mathrm{CO}_{2}$ concentrations. The incubation period for the other cultivars varied from 7 to 12 days, with no difference $(P=0.05)$ in the different treatments. For Seleção 8 , the period of incubation was 30.18 days (Table 3 ).

If considering that Seleção 8 takes approximately 122 days between pruning and fruit maturation, in case of plant infection after pruning, a Pl of 30 days corresponds to $25 \%$ of the total time for cultivation, representing a reduction in the epidemics. Climate change will alter the current scenario of phytosanitary problems. According to Ghini et al. (2007), the economic, social and environmental impacts caused can be positive, negative or neutral, as climate change could decrease, increase or have no effect on the different phytosanitary problems in each region. In eucalypt, Santos et al. (2013) found that the increase of $\mathrm{CO}_{2}$ concentration reduced the incubation period of Ceratocystis fimbriata.
The increased concentration of $\mathrm{CO}_{2}$ reduced the severity of bacterial canker for $\mathrm{cv}$. Sugraone and Seleção 8. Cultivars Italia and Crimson did not present a significant difference regarding the $\mathrm{CO}_{2}$ increase. In the seedlings of grape vine submitted to $390 \mu \mathrm{mol} / \mathrm{mol} \mathrm{CO}_{2}$, a significant difference was observed for severity among the grape cultivars $(P=0.05)$ (Table 4). The same was found for the seedlings subjected to $770 \mu \mathrm{mol} / \mathrm{mol} \mathrm{CO}_{2}$. Sugraone and Seleção 8 cultivars showed the lowest percentages of SEV of the disease, not differing from each other (Table 4).

For the $\mathrm{CO}_{2}$ concentration of 390 $\mu \mathrm{mol} / \mathrm{mol}$, Italia and Crimson Seedless cultivars presented a lower AUDPC. At the concentration of $770 \mu \mathrm{mol} / \mathrm{mol}, \mathrm{cv}$. Sugraone and Seleção 8 presented a significant reduction of AUDPC from 210.25 to 90.75 and 310.50 to 110.25 , respectively (Table 5).

With the results obtained in this study, it can be inferred that the grape vine cultivars have different responses to $\mathrm{CO}_{2}$ concentration increase. Nowadays it is known that natural surface openings and wounds are passive ports for bacterial entry. Stomata regulate gas exchange between the plant and environment,

Table 3. Period of incubation (PI) (days) of bacterial canker in seedlings of grape cultivars subjected to two levels of $\mathrm{CO}_{2}$. Petrolina/PE, Brazil

\begin{tabular}{cllll}
\hline \multirow{2}{*}{ Concentration of $\mathrm{CO}_{2}(\mu \mathrm{mol} / \mathrm{mol})$} & \multicolumn{4}{c}{ Grape cultivars / PI } \\
\cline { 2 - 5 } & Ttalia & Crimson & Sugraone & Seleção 8 \\
\hline 390 & $12.68 \mathrm{aA}$ & $9.87 \mathrm{aA}$ & $7.25 \mathrm{aA}$ & $7.93 \mathrm{aA}$ \\
770 & $9.75 \mathrm{aB}$ & $9.12 \mathrm{aB}$ & $9.25 \mathrm{aB}$ & $30.18 \mathrm{bA}$ \\
\hline $\mathrm{CV}(\%)=21.18$ & \multicolumn{4}{c}{} \\
\hline Means followed by the same uppercase letter in the column and lowercase letter in the row do not differ by the Scott-knott test at 5\% probability.
\end{tabular}

Table 4. Severity (\%) of bacterial canker in seedlings of grape cultivars subjected to 390 and $770 \mu \mathrm{mol} / \mathrm{mol}^{\circ} \mathrm{CO}_{2}$. Petrolina/PE, Brazil

\begin{tabular}{cllll}
\hline \multirow{2}{*}{ Concentrations of $\mathrm{CO}_{2}(\mu \mathrm{mol} / \mathrm{mol})$} & \multicolumn{4}{c}{ Varieties / Severity } \\
\cline { 2 - 5 } & Italia & Crimson & Sugraone & Seleção 8 \\
\hline 390 & $6.81 \mathrm{aC}$ & $5.37 \mathrm{aC}$ & $9.31 \mathrm{aB}$ & $13.25 \mathrm{aA}$ \\
770 & $6.12 \mathrm{aA}$ & $5.25 \mathrm{aA}$ & $3.31 \mathrm{bB}$ & $2.06 \mathrm{bB}$ \\
\hline $\mathrm{CV}(\%)=49.04$ & \multicolumn{5}{c}{} \\
\hline Means followed by the same lowercase letter in the column and uppercase letter in the row do not differ by the Scott--Knott test at 5\% probability.
\end{tabular}

Table 5. Area under the disease progress curve (AUDPC) of bacterial canker inoculated in seedlings of grape cultivars subjected to 390 and $770 \mu \mathrm{mol} / \mathrm{mol} \mathrm{CO}_{2}$. Petrolina/PE, Brazil

\begin{tabular}{cllll}
\hline Concentrations of $\mathrm{CO}_{2}(\mu \mathrm{mol} / \mathrm{mol})$ & \multicolumn{4}{c}{ Grape cultivars / AUDPC } \\
\cline { 2 - 5 } & Italia & Crimson & Sugraone & Seleção 8 \\
\hline 390 & $154.75 \mathrm{aBC}$ & $132.50 \mathrm{aC}$ & $210.25 \mathrm{aB}$ & $310.50 \mathrm{aA}$ \\
770 & $137.50 \mathrm{aA}$ & $116.50 \mathrm{aA}$ & $90.75 \mathrm{bA}$ & $110.25 \mathrm{bA}$ \\
\hline $\mathrm{CV}(\%)=38.38$ & & & \\
\hline Means followed by the same lowercase letter in the column and uppercase letter in the row do not differ by the Scott-Knott test at 5\% probability.
\end{tabular}


and water loss control by changing the stomatal pore size. This stomatal movement is affected by several environmental stimulus, such as $\mathrm{CO}_{2}$ concentration and other one (Melotto et al., 2008).

Thus, climate change may alter the physiology and resistance of the host plant and modify the stages and rates of pathogens development (Yáñez-López et al., 2012). The reduction in the stomatal opening may have played a part in the reduction of the disease for cultivar Sugraone and Seleção 8, by diminishing the specific area for pathogen penetration. These pieces of information are important for grape vine varieties choice to be cultivated in the future climate scenarios.

In studies on the plant-pathogen interaction involving elevations in the $\mathrm{CO}_{2}$ levels, Lake \& Wade (2009) observed that resistant varieties of Arabidopsis thaliana treated with concentrations of $800 \mu \mathrm{mol} / \mathrm{molCO}_{2}$ presented a greater number of stomata, becoming more sensitive to mildew (Erysiphe cichoracearum de Candolle). Aiming to evaluate the effects of air$\mathrm{CO}_{2}$ concentration increase on leaf-spot caused by Cylindrocladium candelabrum in Eucalyptus urophylla, Silva \& Ghini (2014) concluded that the high concentration of $\mathrm{CO}_{2}$ decreased the disease incidence and severity.

The same was observed by Eastburn et al. (2010) for mildew of soybean (Peronospora manshurica (Naum. Syd.). However, Lessin \& Ghini (2009) evaluated the severity of mildew (Microsphaera diffusa Cooke \& Peck) in different soy varieties and observed that $\mathrm{CO}_{2}$ concentration increase resulted in enhanced disease severity.

Few research studies have been conducted aiming to determine the effects of $\mathrm{CO}_{2}$ air concentration increase on occurrence of bacterial disease. Developments should occur to elucidate how different genotypes react to the climate change scenarios, because, as observed in this study, the grape vine cultivars show different responses to infection by $X$. campestris pv viticola.

\section{Conclusions}

The results obtained in this study demonstrated that temperature variation and carbon dioxide concentration of the air have different effects and consequently have different responses to increase the bacterial canker of grapevine.

\section{Acknowledgments}

The authors thank to Embrapa Semiarid for contribution to the experiment and to Universidade do Estado da Bahia - UNEB.

\section{References}

Beriam, L.O.S., Almeida, I.M.G., Patrício, F.R.A. 2011. Impacto potencial das mudanças climáticas sobre as doenças bacterianas no Brasil. In: Ghini, R., Hamada, H., Bettiol, W. Impactos das mudanças climáticas sobre doenças de importantes culturas no Brasil. Embrapa Meio Ambiente, Jaguariúna, Brasil. p. 87-104.

Chakraborty, S., Newton, A.C. 2011. Climate change, plant diseases and food security: an overview. Plant Pathology 60: 2-14.

DallaPria, M., Christiano, R.C.S., Furtado, E.L., Amorim, L., Bergamin Filho, A. 2006. Effect of temperature and leaf wetness duration on infection of sweet oranges by Asiatic citrus canker. Plant Pathology 55: 657-663.

Eastburn, D.M., Degennaro, M.M., Delucia, E.H., Dermody, O., Mcelrone, A.J. 2010. Elevated atmospheric carbon dioxide and ozone alter soybean diseases at SoyFACE. Global Change Biology 16: 320-330.

Garrett, K.A., Dendy, S.P., Frank, E.E., Rouse, M.N., Travers, S.E. 2006. Climate change effects on plant disease: genomes to ecosystems. Annual Review of Phytopathology 44: 489-509.

Ghini, R., Hamada, E., Angelotti, F., Costa, L.B., Bettiol, W. 2012. Research approaches, adaptation strategies, and knowledge gaps concerning the impacts of climate change on plant diseases. Tropical Plant Pathology 37: 5-24.

Ghini, R., Hamada, E., Pedro Júnior, M.J., Gonçalves, R.R.V. 2011. Incubation period of Hemileia vastatrix in coffee plants in Brazil simulated under climate change. Summa Phytopathologica 37: 85-93.

Ghini, R., Hamada, E., Gonçalves, R.R.V., Gasparotto, L., Pereira, J.C.R. 2007. Análise de Risco das Mudanças Climáticas Globais sobre a Sigatoka-negra da Bananeira no Brasil. Fitopatologia Brasileira 32: 197-204. 
IPCC. 2007. Summary for Policymakers. In: Solomon, S., D. Qin., M. Manning., Z. Chen, M. Marquis, K.B. Averyt., M. Tignor; H.L. Miller. Climate Change 2007: The Physical Science Basis. Contribution of Working Group I to the Fourth Assessment Report of the Intergovernmental Panel on Climate Change. Cambridge University Press, Cambridge, United Kingdom and New York, NY, USA, 18.

IPCC. 2013. Summary for Policymakers. In: Stoker, T.F., D. Qin., G-K. Plattner, M. Tignor, S.K. Allen, J. Boschung, A. Nauels, Y. Xia, V. Bex, P.M. Midgley. Climate Change 2013: The Physical Science Basis. Contribution of Working Group I to the Fifth Assessment Report of the Intergovernmental Panel on Climate Change. Cambridge University Press, Cambridge, United Kingdom and New York, NY, USA, 33.

Lake, J.A., Wade, R.N. 2009. Plant-pathogen interactions and elevated $\mathrm{CO}_{2}$ : morphological changes infavour of pathogens. Journal of Experimental Botany 60: 3123-3131.

Lessin, R.C., Ghini, R. 2009. Efeito do aumento da concentração de $\mathrm{CO}_{2}$ atmosférico sobre o oídio e o crescimento de plantas de soja. Tropical Plant Pathology 34: 385-392.

Lima, M.F., Ferreira, M.A.S.V. 2012. Doenças causadas por bactérias. In: Lima, M.F, Moreira, F.R.B. Uva de mesa: Fitossanidade. Embrapa, Brasília, Brasil. p.33-40

Lima, M.F., Ferreira, M.A.S.V., Moreira, W.A. Dianese, J.C. 1999. Bacterial canker of grape vine in Brazil. Fitopatologia Brasileira 24: 440-443.

Malavolta Júnior, V.A., Beriam, L.O.S., Almeida, I.M.G., Rodrigues Neto, J., Robbs, C.F. 2008. Bactérias fitopatogênicas assinaladas no Brasil: uma atualização. Summa Phytopathologica 34 9-88.

Marcuzzo, L.L., Fernandes, J.M.C., Becker, W.F. 2009. Influência da temperatura e da duração do molhamento foliar na severidade da mancha bacteriana do tomateiro. Summa Phytopathologica 35: 229-230.

Melotto, M., Underwood, W., Yang He, S. 2008. Role of Stomata in Plant Innate Immunity and Foliar Bacterial Diseases. Annual Review Phytopathology 46: 101-122.

Nascimento, A.R.P., Michereff, S.J., Mariano, R.L.R., Viana, I.O. 2006. Reação de clones da videira a Xanthomonas campestris pv. viticola, baseada nos componentes epidemiológicos do cancro bacteriano. Ciência Rural 36: 1-7.

Nascimento, A.R.P., Michereff, S.J., Mariano, R.L.R., Gomes, A.M.A. 2005. Elaboração e validação de escala diagramática para cancro bacteriano da videira. Summa Phytopathologica $31: 59-64$

Parlevliet, J.E. 1979. Components of resistance that reduce the rate of epidemic developmente. Annual Review of Phytopathology 17: 203-222.

Rodrigues Neto, J., Destéfano, S.A.L., Rodrigues, L.M.R., Pelloso, D.S., Oliveira Júnior, L.C. 2011. Grapevine bacterial canker in the State of São Paulo, Brazil: detection and eradication. Tropical Plant Pathology 36: 42-44.

Romeiro, R.S. 2005. Bactérias fitopatogênicas. UFV, Viçosa, Brasil. 417p.

Santos, M.S., Ghini, R., Fernandes, B.V., Silva, C.A. 2013. Increased carbon dioxide concentration in the air reduces the severity of Ceratocystis wilt in Eucalyptus clonal plantlets. Australasian Plant Pathology 42: 595-599.

Shaner, G., Finney, R.E. 1977. The effect of nitrogen fertilization on the expression of slow-mildewing resistance in knox wheat. Phytopathology 15: 1051-1056.

Shin, J.W., Yun, C. 2010. Elevated $\mathrm{CO}_{2}$ and temperature effects on the incidence of four major chili pepper diseases. Plant Pathology Journal 26: 178-184.

Silva, C.E.O., Ghini, R. 2014. Crescimento de plantas e severidade da mancha foliar em eucalipto a diferentes concentrações de $\mathrm{CO}_{2}$ no ar. Pesquisa Agropecuária Brasileira 49: 232-235.

Yáñez-López, R., Torres-Pacheco, I., GuevaraGonzález, R.G., Hernández-Zul, M.I., QuijanoCarranza, J.A., Rico-García, E. 2012. The effect of climate change on plant diseases. African Journal of Biotechnology 11: 2417-2428. 